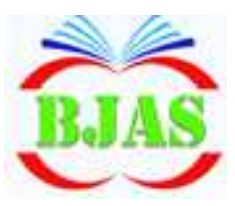

ISSN $1814-5868$
Available online at http://journal.bajas.edu.iq

College of Agriculture, University of Basrah

DOi:10.21276/basjas

Basrah J. Agric. Sci., 31(2): 53-64, 2018

\section{Basrah Journal of Agricultural Sciences}

E-ISSN: 2520-0860

\title{
In Vitro Antimicrobial Activity of Aqueous-Methanolic Extract of Populus sp. Leaves
}

\author{
Husein. A. Husein ${ }^{1}$, Dhurgham. A.H. Alhasan ${ }^{2}$ \& Majid. A.Z. Albadry ${ }^{3}$ \\ ${ }^{1}$ College of Pharmacy, University of Thi-Qar, Iraq \\ ${ }^{2}$ College of Veterinary Medicine, University of Thi-Qar, Iraq. \\ ${ }^{3}$ Education Directorate of Thi-Qar, Ministry of Education, Iraq. \\ *Corresponding author e-mail: dhurghamalhasan@gmail.com \\ Received 17 December 2018; Accepted 5 February 2019; Available online 8 February 2019
}

\begin{abstract}
Plants are a rich source of giving benefit natural products, including antimicrobial agents. The current study was designed to evaluate the antimicrobial activity of Populus sp. leaves that the aqueous methanolic extract $\left(200 \mathrm{mg} \cdot \mathrm{ml}^{-1}\right)$ of the leaves revealed antimicrobial effects against some microbial pathogens in which the highest inhibition zone was recorded against Candida albicans followed by Staphylococcus aureus but no effects on the growth of both Streptococcus mutans and Klebsiella $\mathrm{sp}$. The chemical tests appeared that the extract contains sterols, terpenoids, carbohydrates, glycosides, flavonoids, tannins, proteins, amino acids, and saponins glycosides while alkaloids were not detected. GC-MS analysis detected the aqueous methanolic extract has four compounds are \{2-Pyridineacetaldehyde,[2-(2-pyridinyl) ethylidene]hydrazone $\}$, \{n-Propylamine, N-acetyl-3-[2-acetyl-3,4,5-trimethoxyphenyl]\},$\{1$-(Methyl propyl)-4-(1',1',2'-trichloro-3'-ethyl allyl)benzene $\}$ and $\{1$ H-Indole, 5methyl-2-phenyl- $\}$.
\end{abstract}

Keywords: Populus sp. leaves, Methanolic Extract, Antimicrobial Activity, GC-MS Analysis.

\section{Introduction}

Medicinal plants are one of the living sources that possess the ability to produce the agents which inhibit the microbial pathogens and cancer cells. (Wolfender et al., 2011; Newman \& Cragg, 2012). The genus of Populus represents the deciduous trees of the angiosperms, Salicaceae family, (Ferreira et al., 2009). $P$. euphratica is commonly known as Euphrates poplar, Salt poplar, and Firat poplar. Ecologically, the species grows along riversides during summertime especially in the environments that are characterized by salinity (Ferreira et al., 2006; Han et al., 2013). Another species of the genus is $P$. nigra L. has ecological and economic importance (Ballian et al., 2006).

Species of the genus Populus were studied to extract the natural products which have antimicrobial and antioxidant activities. The 
extracts of $P$. euphratica leaves gave antimicrobial effects on the growth of some bacteria (Badi et al., 2016). In Iraq, researchers extracted polyphenolic compounds from the leaves of that species (Kredy et al.,2015). Native peoples in North America and Eurasia used $P$. tremuloides to be as traditional medicines for treating their diseases such as venereal diseases and arthritis (Royer et al., 2012; St-Pierre et al., 2018). Other investigators noted that the extracts of $P$. alba had antibacterial and antioxidant effects (Al-Hussaini \& Mahasneh, 2011; Boudkhili et al., 2012; Haouat et al., 2013).

The present study was conducted to get two aims. The first aim was to evaluate the antimicrobial activity of the crude aqueous methanolic extract from Populus sp. leaves while the second was to detect the constituents of the extract by using chemical tests and GC-MS analysis.

\section{Material and Methods}

\section{Preparation of Sample and Its Extraction}

Healthy leaves of Populus sp. (Fig. 1), growing in Thi-Qar Province, Iraq, were collected on August 2018. The leaves were washed with tap water, then by distilled water, and left at room temperature for 3 days until they dried. By using a small mill, the dried leaves were pulverized and grinded to be a powder. $200 \mathrm{~g}$ of the powder were placed in a clean glass beaker (1000 ml-size), and $700 \mathrm{ml}$ of petroleum ether were poured on the powder to be soaked. Through using two layers of parafilm, the beaker was strictly covered and left at the room temperature for 4 days. The soaked powder was separated from the filtrate by a filter paper containing $0.5 \mathrm{~g}$ of activated charcoal as a film to remove the chlorophyll pigment. At the room temperature, the filtrate and powder were separately left until petroleum ether evaporated completely for obtaining the powder had no petroleum ether. At the same conditions of petroleum ether method except for time period, the same powder (powder had no petroleum ether) was soaked with $700 \mathrm{ml}$ of aqueous methanol $(20 \mathrm{ml}$ of distilled water: $80 \mathrm{ml}$ of absolute methanol) for 7 days. The filtrate was separated from the soaked powder and evaporated like a filtrate of petroleum ether for giving sticky extract that was tested against some microbial pathogens.

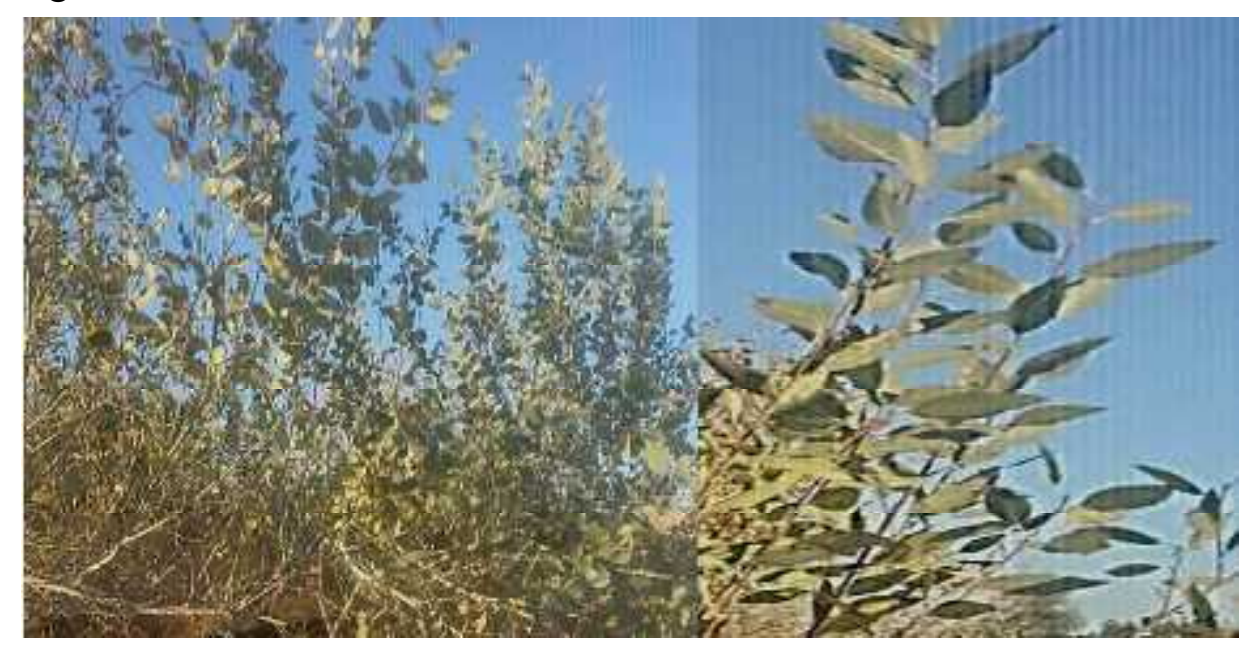

Fig. (1): Healthy leaves of Populus sp. from Thi-Qar Province-Iraq.

\section{Antimicrobial Activity of Aqueous Methanolic Extract}

Amount of the aqueous methanolic extract was dissolved in the dimethyl sulfoxide (DMSO) for getting a concentration was 200 $\mathrm{mg} \cdot \mathrm{ml}^{-1}$. Petri dishes of both Muller Hinton agar (MHA) and potato dextrose agar (PDA) were prepared. The MHA dishes were used to test the bacteria while the dishes of PDA were prepared for testing Candida albicans. Each dish of both MHA and PDA was inoculated with $100 \mu \mathrm{L}$ of $1.5 \times 10^{9}$ cell.ml ${ }^{-1}$ from the microbial suspension. The inoculum was 
spread on the dish by using a sterile cotton swab. After drying the dishes, well $(7 \mathrm{~mm}$ in size) was done in each dish. $100 \mu \mathrm{L}$ of the concentration was placed in the well and incubated at $37^{\circ} \mathrm{C}$ for 2 days until the zones of inhibition were given around the tested microorganisms. C. albicans incubated at both 25 and $37^{\circ} \mathrm{C}$. Also, a disc contained 30 $\mu \mathrm{g} \backslash \mathrm{ml}$ of the pure tetracycline was used a control agent against bacteria.

\section{Chemical Tests of Aqueous Methanolic Extract}

The chemical tests were performed according to (Chang et al., 2002; Shah and Seth, 2010; Sabri et al., 2012; Gupta et al., 2013; Rahman et al., 2013) and as follow:

\section{Detection of Sterol and Terpenoids}

1-Salkowski's Test: $2-3$ drops of the plant extract solution were treated with $2 \mathrm{ml}$ of chloroform, then filtered to obtain a filtrate. Without shacking, few drops of concentrated sulphuric acid were carefully added on the side of a test tube containing the filtrate. If the reddish brown color of the interface appears, it indicates the presenting terpenoids while the appearing golden yellow color indicates the presenting triterpenes.

2-Libermann Burchard's Test: $2 \mathrm{ml}$ of the plant extract solution were treated with chloroform, then filtered to obtain a filtrate. Few drops of acetic anhydride were added into the filtrate which boiled and cooled. Then few drops of concentrated sulphuric acid were carefully added on the sides of the test tube. If brown ring at the junction forms, it indicates the presenting phytosterols (however; the color begins to appear red, then blue and finally green color indicates the presence of sterols).

3- Copper Acetate Test: $2-3 \mathrm{ml}$ of plant extract solution were treated with few drops of $5 \%$ copper acetate solution. If emerald green color appears, it indicates the presenting diterpenes.

\section{Detection of Alkaloids}

1-Wagner's Test: 2-3 $\mathrm{ml}$ of the plant extract solution were treated with $2 \mathrm{ml}$ of Wagner's reagent (Iodine in potassium iodide). If brown/reddish brown precipitate forms, it indicates the presenting alkaloids.

2- Dragendroff's Test: Acidifying 2-3 $\mathrm{ml}$ of plant extract solution with 1 drop of sulfuric acid. The acidified extract was treated with $0.5 \mathrm{ml}$ of Dragendroff's reagent (solution of potassium bismuth iodide). If red precipitate forms, it indicates the presenting alkaloids.

\section{Detection of Carbohydrates}

1-Molisch's Test: 2-3 $\mathrm{ml}$ of the plant extract solution were treated with few drops of $10 \%$ alcoholic $-\alpha$ - naphthol solution (2-4 drops ), then about $2 \mathrm{ml}$ of concentrated sulphuric acid were carefully added to the side of the test tube. If purple color appears, it indicates presenting carbohydrates.

2- Benedict's Test: 2-3 $\mathrm{ml}$ of the plant extract solution were treated with $0.5-1 \mathrm{ml}$ of commercial Benedict's reagent. The mixture was boiled by using a water bath for 4-10 minutes, then cooled. If a precipitate of reddish brown color forms, it indicates the presenting carbohydrates while orange-red precipitate indicates the presenting reducing sugars.

\section{Detection of Glycosides}

1- General Test: $5 \mathrm{ml}$ of the plant extract solution were treated with few drops of $10 \%$ aqueous $\mathrm{NaOH}$ solution. If yellow color develops, it indicates the presenting glycoside.

2-Raymond's test: $3 \mathrm{ml}$ of the plant extract solution were treated with hot methanolic alkali (sodium hydroxide). If a violet color appears, it indicates the presenting glycoside.

3- Keller Kiliani Test (for deoxysugar glucosides): adding $2 \mathrm{ml}$ of glacial acetic acid containing a few drops (3-4) of $5 \% \mathrm{FeCl} 3$ solution to 2-3 $\mathrm{ml}$ of the plant extract solution. Then, adding $1 \mathrm{ml}$ of concentrated $\mathrm{H} 2 \mathrm{SO} 4$ along the side of the test tube carefully. If a reddish-brown ring at the interface forms, it indicates the presenting deoxysugar of cardenolides. Appearing violet ring may form beneath the brown ring, while in the acetic acid layer, a greenish ring may also form just gradually throughout the layer. 
4- Legal Test: Acidifying $2 \mathrm{ml}$ of the plant extract solution with 1 drop of concentrated $\mathrm{HCl}$, then treatment with $1 \mathrm{ml}$ sodium nitroprusside in $1 \mathrm{ml}$ pyridine and methanolic alkali. If pink to bloody color appears, it indicates the presenting cardiac glycosides.

\section{Detection of Coumarin Glycosides, Phenolic Compounds, Flavonoids, and Tannins}

1- Alkaline Reagent Test: $2-3 \mathrm{ml}$ of the plant extract solution were treated with few drops of $20 \%$ sodium hydroxide solution. If intense yellow color appears (that turns to colorless by adding few drops of dilute acetic acid), it indicates the presenting flavonoids.

2-Lead Acetate Test: $2 \mathrm{ml}$ of the plant extract solution were treated with few drops of $10 \%$ lead acetate solution. If white precipitate forms, it indicates the presenting phenolic compounds.

3-Ferric Chloride Test: about $1 \mathrm{ml}$ of the plant extract solution was added to $2 \mathrm{ml}$ of water by using a test tube. Adding 2-3 drops of diluted 5\% ferric chloride solution. If green - bluish green appears, it indicates Catechic tannins while blue-black indicates Gallic tannins.

4-Gelatin Test: $2-3 \mathrm{ml}$ of the plant extract solution were added to a $1 \%$ gelatin solution containing sodium chloride $(1 \%)$. If white precipitate forms, it indicates the presenting tannins.

\section{Detection of Proteins and Amino Acids}

1-Xanthoproteic Test: $3 \mathrm{ml}$ of the plant extract solution were treated with few drops of concentrated nitric acid. If yellow color appears, it indicates the presenting proteins.

2-Ninhydrin Test: $3 \mathrm{ml}$ of the plant extract solution were treated with few drops of $2 \%$ $(\mathrm{w} / \mathrm{v})$ ethanolic ninhydrin reagent, and boiled for 5-10 minutes. If a blue color appears, it indicates the presenting amino acid.

3-Biuret Test: $3 \mathrm{ml}$ of the plant extract solution were treated with $1 \mathrm{ml}$ of $10 \%$ sodium hydroxide solution and heated, then a drop of $0.7 \%$ copper sulfate solution was added. If purplish violet color appears, it indicates the presenting proteins.

\section{Detection of Saponine Glycosides}

1- Foam Test: $1 \mathrm{ml}$ of the plant extract solution was added to 2-3 $\mathrm{ml}$ of distilled water. The mixture was shaken vigorously. If foam forms (persists for 10 minutes), it indicates the presenting saponins.

2-Froth Test: Diluting $1 \mathrm{ml}$ of the plant extract solution with distilled water to get 20 $\mathrm{ml}$. The diluted solution of the extract was shook by a graduated cylinder for 15 minutes. If $1 \mathrm{~cm}$ layer of foam forms ( persists for 15 minutes), it indicates the presenting saponins.

Gas Chromatography-Mass Spectrometry Analysis (GC-MS) of Aqueous Methanolic Extract

Dissolving an amount of the crude aqueous methanolic (80\%) extract in DMSO, and filtered by using $\mu \mathrm{M} \quad 0.45$ filter syringe (Millipore). The filtrate was subjected to be analyzed by gas chromatography-mass spectrometry, $\quad$ MSDCHEM $\backslash 1 \backslash$ METHODS $\backslash$ MUAFAQ.M to determine the negative ions $(\mathrm{m} / \mathrm{z})$ by which the used column was characterized by HP-5MS, 5\% Phenyl methyl Sillox(1629.5), $30 \mathrm{~m} \times 0.250 \mu \mathrm{m}$ I.D. $\times 0.25$ $\mu \mathrm{m}$, SS., Inlet $\mathrm{He}$, then applying the parameters showing in (Table 1).

\section{Preliminary Assay of Cytotoxicity Against Red Blood Cells (RBCs)}

The assay of the extract against human red blood cell (RBCs) was performed according to Nair et al., (1989). $1 \mathrm{ml}$ of human blood $(\mathrm{O}+)$ was mixed with $20 \mathrm{ml}$ of normal saline for preparing a blood solution. Three plastic tubes were used that each tube contained $2 \mathrm{ml}$ of the solution. Two of them were used as control tubes where one tube was negative control contained $2 \mathrm{ml}$ of the blood solution only while the second one was positive control had $100 \mu \mathrm{L}$ of DMSO mixed with the $2 \mathrm{ml}$ of the solution. The third tube contained blood solution and $100 \mu \mathrm{L}$ of $200 \mathrm{mg} \cdot \mathrm{ml}^{-1}$ obtained from an aqueous methanolic extract. 
Husein et al. / Basrah J. Agric. Sci., 31 (2): 53-64, 2018

Table (1): Used parameters of GC-MS to detect the compounds within aqueous methanolic $(80 \%)$ extract from leaves of Populus sp.

\begin{tabular}{|l|c|}
\hline \multicolumn{2}{|c|}{ Analysis Parameters } \\
\hline EMV mode & Gain Factor (1.00) \\
\hline Resulting EM voltage & 1306 \\
\hline Power capacity & $70 \mathrm{EV}$ \\
\hline Low Mass & 28.0 \\
\hline High Mass & 441 \\
\hline Threshold & 150 \\
\hline Minimum quality for all narcotics & $90-97 \%$ \\
\hline Flow rate & $1 \mathrm{ml} / \mathrm{min}$ \\
\hline Runtime & $24 \mathrm{~min}$ \\
\hline Hold up time & $1.5288 \mathrm{~min}$ \\
\hline Solvent delay & $3.00 \mathrm{~min}$ \\
\hline Average velocity & $36.796 \mathrm{~cm} / \mathrm{sec}$ \\
\hline Temperature & $8.81 \mathrm{Psi}$ \\
\hline Pressure & Initial $70^{\circ} \mathrm{C}$ to Maximum $375^{\circ} \mathrm{C}$ \\
\hline
\end{tabular}

All tubes were incubated at room temperature for $1 \mathrm{hr}$. If the color of blood solution changed to be pale color compared with control tubes, it indicates the hemolysis due to a concentration of the extract.

\section{Statistical analysis}

The statistical analysis was performed by using program of Graph Pad Prism 5 and One- way ANOVA.

\section{Results}

\section{Antimicrobial Activity of Aqueous Methanolic Extract}

The aqueous methanolic extract (200 mg. $\left.\mathrm{ml}^{-1}\right)$ had antimicrobial activity against a growth of $C$. albicans followed by $S$. aureus, then $E$. coli, while the extract could not inhibit the growth of both S. mutans and Klebsiella sp. The antibacterial activity of the extract was compared with a disc contained $30 \mu \mathrm{g} \backslash \mathrm{mlof}$ the pure tetracycline. Statistical analysis showed significant differences among tested microorganisms (Table 2,Figs. $2 \& 3$ ).

Table (2): Antimicrobial activity of aqueous methanolic extract obtained from Populus sp. leaves.

\begin{tabular}{|c|c|c|c|c|c|}
\hline \multicolumn{7}{|c|}{ Inhibition Zones (IZ) Measured by Milliliter (mm) } \\
\hline \multicolumn{2}{|c|}{ S. aureus } & S. mutans & E. coli & Klebsiella sp. & C. albicans \\
\hline Ext. & 10 & 0 & 7 & 0 & 20 \\
\hline Tet. & 36 & 36 & 0 & 5 & ---- \\
\hline
\end{tabular}

Ext.: $200 \mathrm{mg} . \mathrm{ml}^{-1}$ aqueous methanolic extract. Tet.: disc contained $30 \mu \mathrm{g} \backslash \mathrm{ml}$ of the pure tetracycline. 

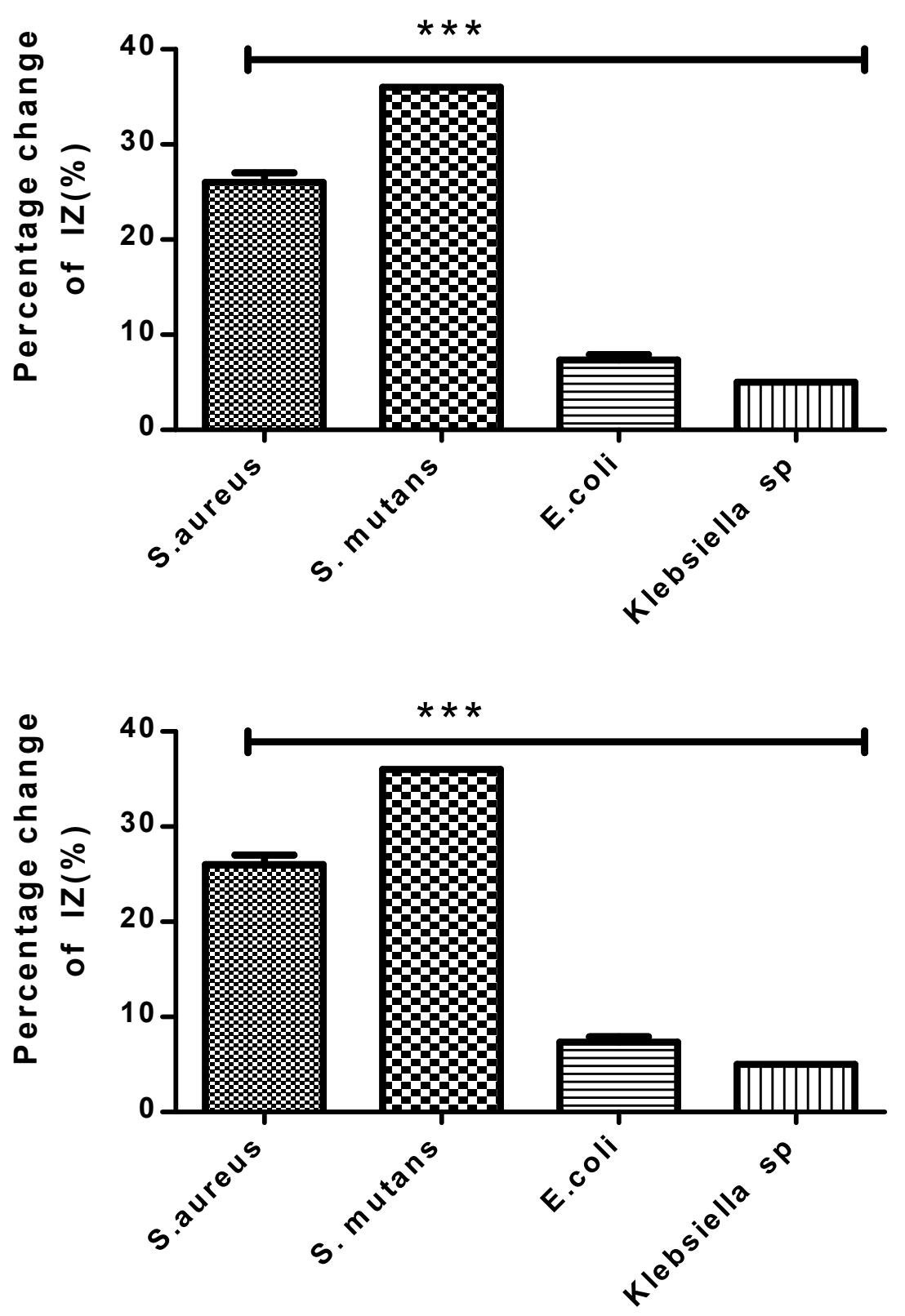

Fig. (2): There were significant differences among tested microorganisms. One-way ANOVA was used, and application of Graph Pad Prism 5 program. One or more stars indicate to present the significant results. IZ: Inhibition zone.

Fig. (3): Antimicrobial activity of aqueous methanolic extract from Populus sp. leaves. The used concentration was $200 \mathrm{mg} \cdot \mathrm{ml}^{-1}$. (A): Against $C$. albicans.

(B): Against $S$. aureus compared with a disc of tetracycline (30 ug $\backslash \mathbf{m l})$.

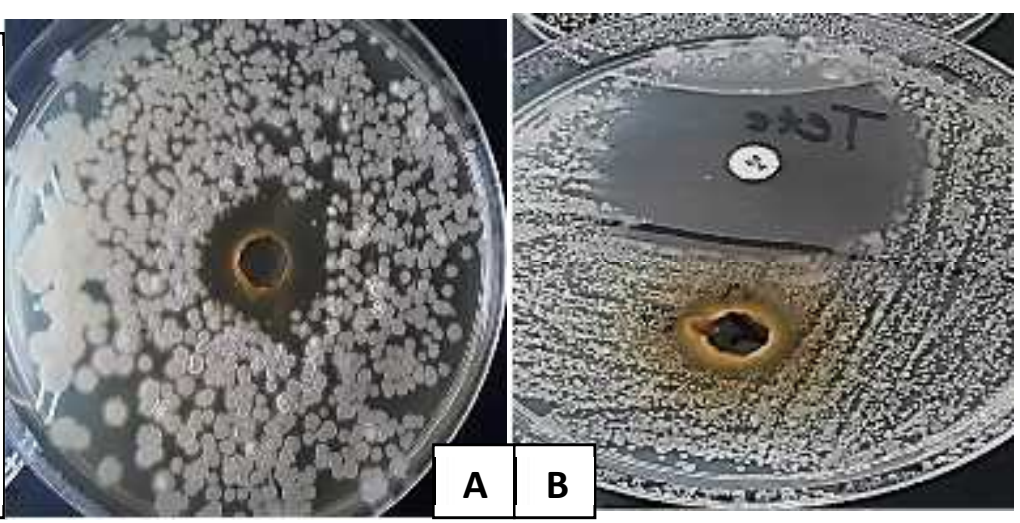


Husein et al. / Basrah J. Agric. Sci., 31 (2): 53-64, 2018

\section{Chemical Tests of Aqueous Methanolic Extract}

The chemical tests resulted in the various compounds within the aqueous methanolic extract of Populus sp. leaves. These compounds are sterols, terpenoids, carbohydrates, glycosides, flavonoids, tannins, proteins, amino acids, and saponins glycosides but alkaloids were not detected in the extract (Table 3). Relating to the chemical tests, the solid extract of petroleum ether filtrate obtained from the leaves of Populus sp. contains sterols and terpenoids besides alkaloids.

Table (3): Compounds of aqueous methanolic and petroleum ether filtrate extracts of Populus sp. leaves were detected by chemical tests.

\begin{tabular}{|c|c|c|}
\hline Type of Test & \multirow[t]{2}{*}{ Methanolic Extract } & \multirow[t]{2}{*}{ Petroleum Ether Extract } \\
\hline Sterol /Terpenoids & & \\
\hline Salkawski's test & -ve & $+\mathrm{ve}$ \\
\hline Liebermann's test & $+\mathrm{ve}$ & $+\mathrm{ve}$ \\
\hline Copper acetate test & +ve (diterpene) & \\
\hline \multicolumn{3}{|l|}{ Alkaloids } \\
\hline Wagner's test & -ve & $+\mathrm{ve}$ \\
\hline Dragendroff's test & -ve & -ve \\
\hline \multicolumn{3}{|l|}{ Carbohydrates } \\
\hline Molisch test & $+\mathrm{ve}$ & $\begin{array}{ll}----- \\
--\end{array}$ \\
\hline Benedict test & $+\mathrm{ve}$ & ------ \\
\hline \multicolumn{3}{|l|}{ Glycosides } \\
\hline General alkaline test & $+\mathrm{ve}$ & ------ \\
\hline Raymond's test & $+\mathrm{ve}$ & ----- \\
\hline Keller Kiliani test & +ve (cardiac glycosides) & ------ \\
\hline Legal test & $+\mathrm{ve}$ & $\begin{array}{ll}----- \\
\end{array}$ \\
\hline \multicolumn{3}{|l|}{ Coumarin Glycosides } \\
\hline Alkaline test & $+\mathrm{ve}$ & ------ \\
\hline \multirow{2}{*}{\multicolumn{3}{|c|}{ Phenolic Compounds }} \\
\hline & & \\
\hline Alkaline test & $+\mathrm{ve}$ & ------ \\
\hline Lead acetate test & $+\mathrm{ve}$ & ------ \\
\hline Ferric chloride test & $+\mathrm{ve}$ & ------ \\
\hline \multicolumn{3}{|l|}{ Tannins } \\
\hline Ferric chloride test & +ve (catechol tannins) & ------ \\
\hline Lead acetate test & $+\mathrm{ve}$ & ------ \\
\hline Gelatin test & -ve & ----- \\
\hline \multicolumn{3}{|r|}{ Proteins and Amino Acids } \\
\hline Xanthoproteic test & $+\mathrm{ve}$ & ------ \\
\hline Ninhydrin test & -ve & ------ \\
\hline Biuret test & $+\mathrm{ve}$ & $\begin{array}{l}----- \\
\end{array}$ \\
\hline \multicolumn{3}{|l|}{ Saponine Glycosides } \\
\hline Foam test & $+\mathrm{ve}$ & ------ \\
\hline Forth test & $+\mathrm{ve}$ & ------ \\
\hline
\end{tabular}

+ve: Positive result. -ve: Negative result. ------: The extract could not dissolve in the solution of the test. 
Husein et al. / Basrah J. Agric. Sci., 31 (2): 53-64, 2018

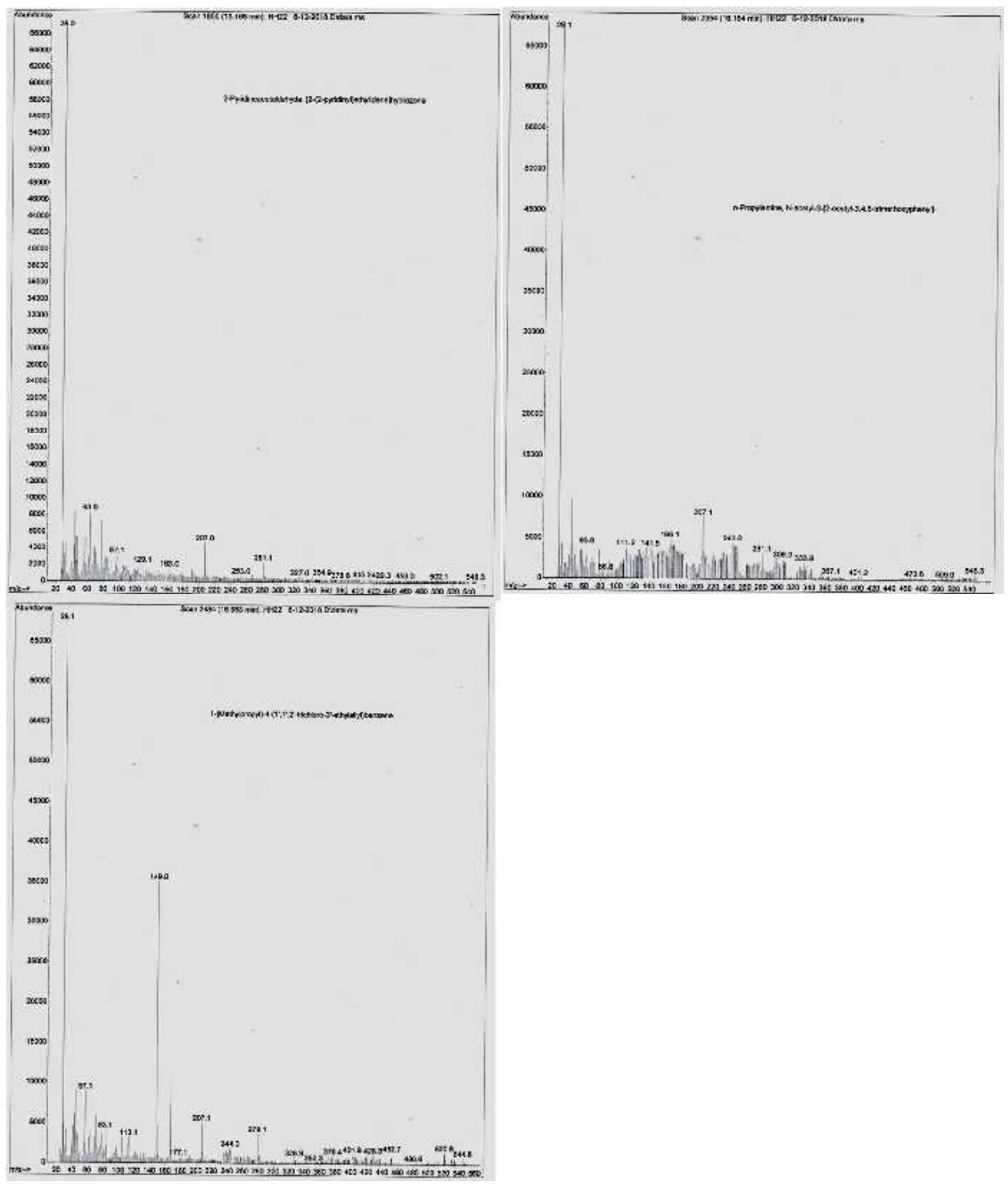

Fig. (4a): The compounds of aqueous methanolic extract produced from leaves of Populus sp. detected by GC-MS analysis. 
Husein et al. / Basrah J. Agric. Sci., 31 (2): 53-64, 2018
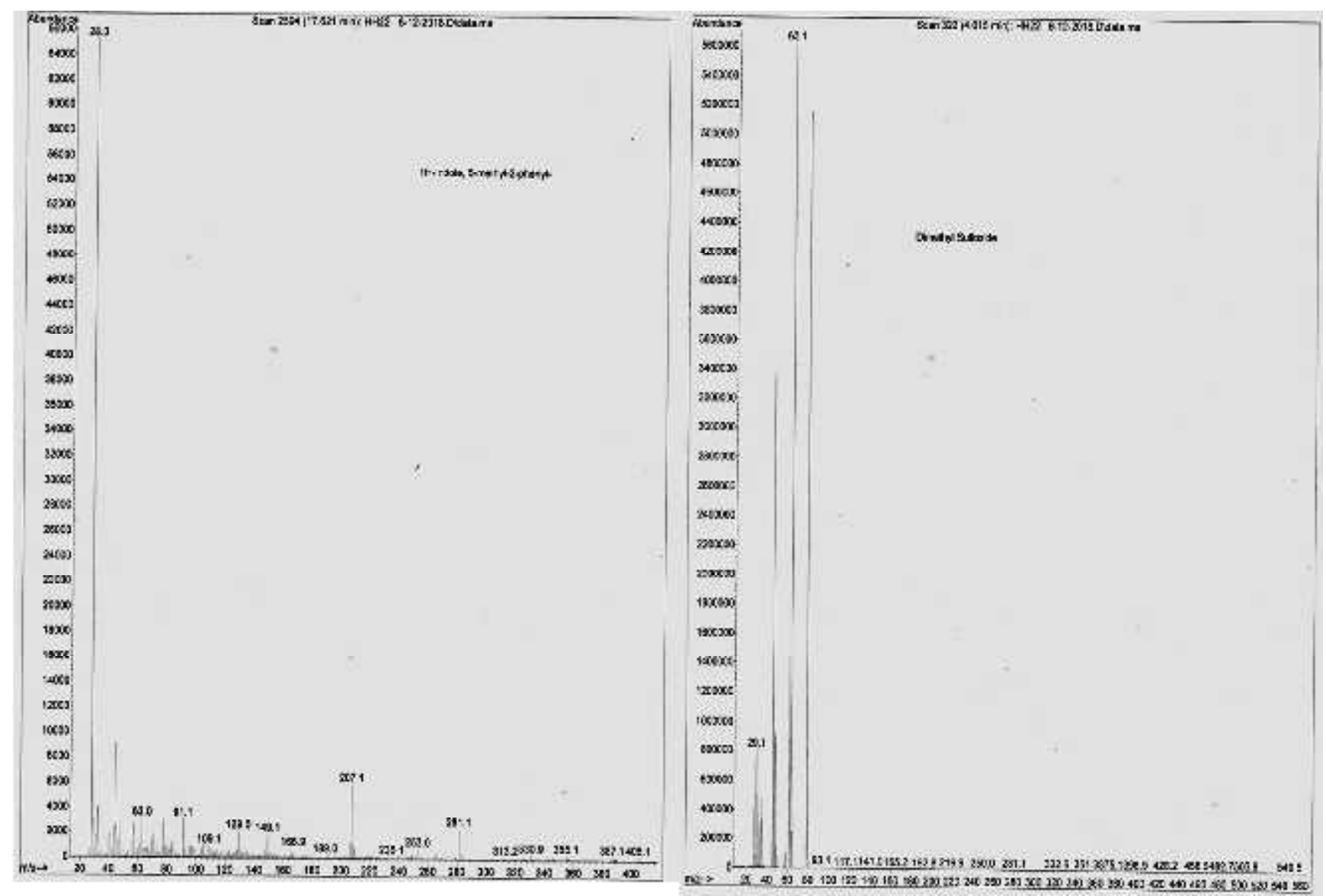

Fig. (4b): The compounds of aqueous methanolic extract produced from leaves of Populus sp. detected by GC-MS analysis. DMSO was detected as a sample solvent.

\section{Extract}

The GC-MS analysis detected four compounds in the aqueous methanolic extract obtained from Populus sp. leaves. Also, the analysis of GC-MS detected DMSO as the sample solvent by which the extract dissolved. The retention times of the compounds were recorded 4.015- 17.621 minutes (Table 4, Figs. 4a \& 4b).

Table (4): The compounds of the aqueous methanolic extract obtained from leaves of Populus sp. detected by GC-MS analysis. (RT: Retention time by the minute).

\begin{tabular}{|c|r|c|}
\hline \multicolumn{2}{|c|}{ Compounds } & RT (min.) \\
\hline 1 & 2-Pyridineacetaldehyde,[2-(2-pyridinyl) ethylidene] hydrazone & 13.166 \\
\hline 2 & n-Propylamine, N-acetyl-3-[2-acetyl-3,4,5-trimethoxyphenyl]- & 16.184 \\
\hline 3 & propyl)-4-(1',1',2'-trichloro-3'-ethylallyl)benzene 1-(Methyl & 16.963 \\
\hline 4 & 1H-Indole, 5-methyl-2-phenyl- & 17.621 \\
\hline 5 & Dimethyl Sulfoxide, DMSO, (Sample solvent) & 4.015 \\
\hline
\end{tabular}

\section{Preliminary Assay of Cytotoxicity Against}

\section{Red Blood Cells}

The used concentration of the aqueous methanolic extract did not give any change in the color of the human blood solution in Comparison with the control tubes during $1 \mathrm{~h}$ of the testing time period but the same concentration changed the color of blood solution into slightly blackish red after 24 hours of the testing time (Fig. 5). 


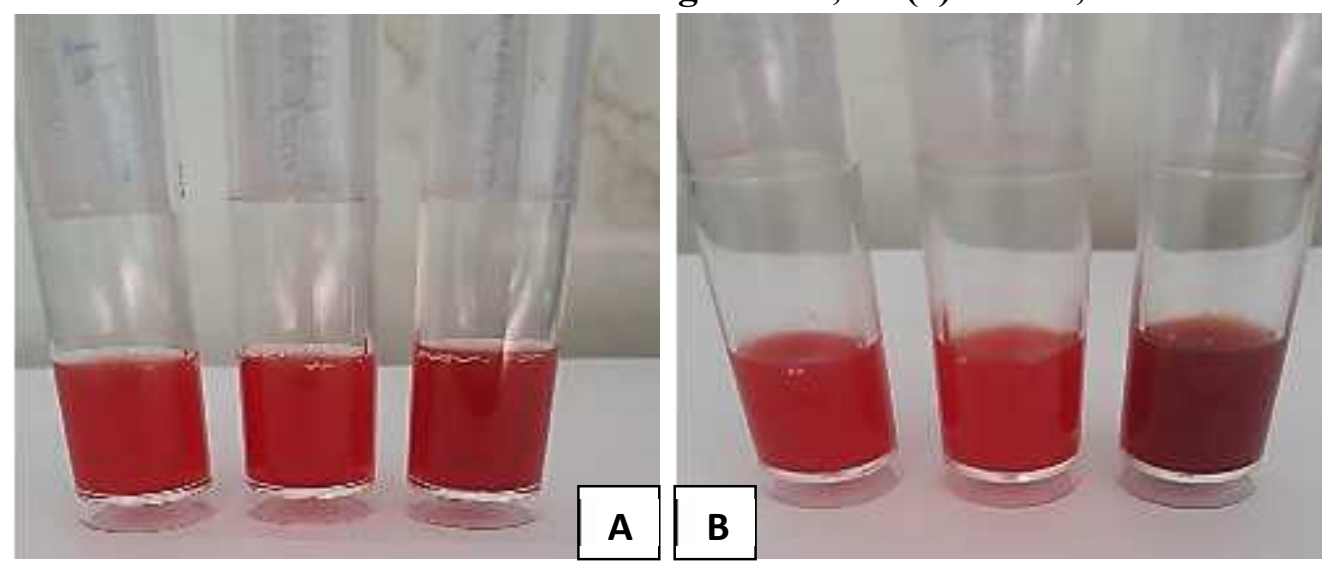

Fig. (5): Preliminary assay of the aqueous methanolic extract against RBCs cytotoxicity. From left to right: The first tube represented negative control tube containing blood solution only (blood mixed with normal saline). The second tube was positive control tube containing 100

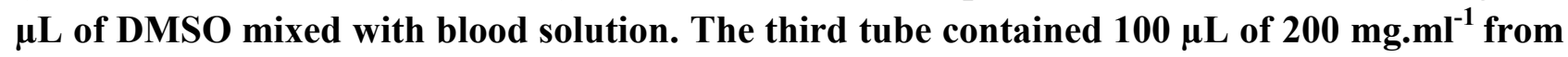
the extract. A: After 1 hr- of the testing time period. B: After 24 hrs- of the testing time period.

\section{Discussion}

Selection of the solvents represents an important and critical step for the extraction because the compounds within the extracts of plants differ in their affinity for the solvents. Petroleum ether is used to extract the fixed and essential oils, as well as sterones (Saroya, 2011). The addition of a polar solvent to the polar one will increase the polarity of the solvents. The plant matrices contain the bioactive compounds which are medium-size molecules due to their aromatic delocalized $\pi$ electrons. This phenomenon indicates that the matrices are highly polar which need to be extracted by polar solvents (Andri et al., 2009; Kumoroa et al., 2009; Altemimi et al., 2017; St-Pierre et al., 2018). For these reasons, our study used two polar solvents were a mixture of absolute methanol and distilled water $(80: 20)$ for extraction the bioactive compounds from leaves of Populus $\mathrm{sp}$. while the petroleum ether was used before aqueous methanol $(80 \%)$ in order to remove the fixed and essential oils besides sterones from the plant pulverized leaves (Table 3).

The plant extracts contain the bioactive compounds such as glycosides, tannins, saponins, phenols which inhibit the growth of microorganisms (Ahmad et al., 1998; Pamplona-Roger, 1999; Shariff, 2001). The effects of these compounds varied according to susceptibility and strains of bacteria (Karou et al., 2006). Based on the mentioned researchers, our results may attribute why the crude extract of aqueous methanol exhibited the antimicrobial effects on some of the tested microorganisms (Tables $2 \& 3$, Figs $2 \& 3$ ).

Hydrazone-derivatives are able to be the antimicrobial, antitumor, anti-inflammatory, antiplatelet agents. These derivatives resulted in the antimicrobial activity against S.aureus, and Mycobacterium tuberculosis (Küçükgüzel et al., 2002; Rollas et al., 2002; Kaymakçığlu et al., 2006). Other scientists showed that indole derivatives such as 4-(5methyl-3-phenyl 1H-indole) inhibited the microbial pathogens such as $S$. aureus and $C$. albicans (Yuksek et al., 2013). Our study showed that GC-MS detected derivatives of both hydrazine indole in the aqueous methanolic extract (Table 4, Figs 4a \& 4b). The GC-MS analysis may explain why the aqueous methanolic extract inhibited some tested microorganisms. It may be thought that the microbial inhibition was due to derivatives of both hydrazine indole within the extract.

\section{Conclusions}

The aqueous methanolic extract of Populus sp. leaves has antimicrobial compounds which very needs to be separated by using techniques of chromatography to extract them as the pure compounds. In vitro and in vivo, the purified compounds can be tested for evaluation of their half lethal concentrations 
$\left(\mathrm{LC}_{50}\right)$ and half lethal dose $\left(\mathrm{LD}_{50}\right)$. Finally, the elucidating chemical structure of these compounds can be given by using techniques of spectrometry such as NMR, GC-MS etc. After applying these biological and chemical analyses, the identified pure compounds are tested on volunteers in order to apply them as drugs for treating microbial diseases in hospitals.

\section{Acknowledgment}

We are grateful for our country, Iraq, and friends for supporting us to perform this paper by which we hope to be a simple step for serving life.

\section{References}

Ahmad, I.; Mehomood, Z. \& Mohammed, F. (1998). Screening of some Indian medicinal plants for their antimicrobial properties. J. Ethnopharma., 62(2): 183193.

Al-Hussaini, R. \& Mahasneh, A.M. (2011). Antibacterial and antifungal activity of ethanol extract of different parts of medicinal plants in Jordan. J. J. Pharmace. Sci., 4(1): 57 -69. (Cited by Boudkhili et al., 2012).

Altemimi, A.; Lakhssassi, N.; Baharlouei, A.; Watson, D.G. \& Lightfoot, D.A. (2017). Phytochemicals: Extraction, isolation, and identification of bioactive compounds from plant extracts. Plants, 6(42): 1-23.

Andri, C.K.; Masitah, H. \& Harcharan, S. (2009). Effects of solvent properties on the soxhlet extraction of diterpenoid lactones from Andrographis paniculata leaves. Sci. Asia., 35: 306-309.

Badi, J.M.; Resen, H.M.; Majeed, A.M. \& Abd Al razak, M.M. (2016). Antimicrobial activity of Populous euphratica leaves extracts on growth of some gram negative bacteria. J. Eng. \& Technol., 34B(5): 169170.

Ballian, D.; Kajba, D. \& Idzojtic, M. (2006). Morphological diversity of hairy European black poplar (Populus nigra subsp. caudina) in Bosnia and Herzegovina. Univ. Banja Luka., 5: 13-22.
Boudkhili, M.; Greche, H.; Bouhdid, S.; Zerargui, F. \& Aarab, L. (2012). In Vitro antioxidant and antibacterial properties of some Moroccan medicinal plants. Int. J. Pharm. Tech. Res., 4(2): 637-642.

Chang, C.C.; Yang, M.H.; Wen, H. \& Chern, M. J. C. (2002). Estimation of total flavonoid content in propolish by two complementary colorimetric methods. J. Food Drug Anal., 10(3): 178-82.

Ferreira, S.; Batista, D.; Serrazina, S. \& Pais, M. (2006). Proteome profiling of Populus euphratica Oliv. upon heat stress. Ann.. Bot.-London, 98 (2): 361-377.

Ferreira, S.; Batista, D.; Serrazin, S. \& Pais, M. (2009). Morphogenesis induction and organogenic nodule differentiation in Populus euphratica Oliv. leaf explants. Plant Cell, Tissue and Organ Culture (PCTOC), 69(1): 35-43.

Gupta, M.; Thakur, S.; Sharma, A. \& Gupta, S. (2013). Qualitative and quantitative analysis of phytochemicals and pharmacological value of some dye yielding medicinal plants, Orient. J. Chem., 29(2): 475-481.

Han, Y.; Wang, W.; Sun, J.; Ding, M.; Zhao, R.; Deng, S.; Wang, F.; Hu, Y.; Wang, Y; et al., (2013). Populus euphratica XTH overexpression enhances salinity tolerance by the development of leaf succulence in transgenic tobacco plants. J. Exp. Bot., 64(14): 42254238 .

Haouat, A.C.; El Guendouzi, S.; Haggoud, A.; David, S.; Sqalli, H.; Ibnsouda, S. \& Iraqui, M. (2013). Antimycobacterial activity of Populus alba leaf extracts. J. Med. Plants Res., 7(16): 1015-1021.

Karou, D.; Savadogo, A.; Canini, A.; Yameogo, S.; Montesano, C.; Simpore, J.; Colizzi, V. \& Traore, A.S. (2006). Antibacterial activity of alkaloids from Sida acuta. Afr. J. Biotechnol., 5: 195-200.

Kaymakçıŏlu, K.B.; Oruç, E.E.; Unsalan, S.; Kandemirli, F.; Shvets, N.; Rollas, S. \& Anatholy, D. (2006). Synthesis and characterization of novel hydrazide- 
hydrazones and the study of their structure antituberculosis activity. Eur. J. Med. Chem., 41: 1253-1261.

Kredy, H. M.; Zaid, A. K.; Affat, S. A. \& Majid, A. (2015). Identification of major phenolic compounds in leaves of Populus euphratica. Basic Res. J. Agric. Sci. Rev., 4(3): 71-74.

Kumoroa, A. C.; Hasana, M. \& Singha, H. (2009). Effects of solvent properties on the soxhlet extraction of diterpenoid lactones from Andrographis paniculata leaves. Sci. Asia, 35: 306-309.

Küçükgüzel, Ş.G.; Oruç E.E.; Rollas S.; Şahin, F. \& Ozbek, A. (2002). Synthesis, characterization and biological activity of novel 4-thiazolidinones, 1,3,4-oxadiazoles, and some related compounds. Eur. J. Med. Chem., 37: 197-206.

Nair, M.G.; Putnam, A.R.; Mishra, S.K.; Mulks, M.H.; Taft, W.H.; Keller, J.E. \& Miller, J.R. (1989). Faeriefungin, a new broad spectrum antibiotic from Streptomyces griseus var. autotrophicus. J. Natur. Prod., 52 (4): 979-809. (Cited by Alfadhul, S.A.M. 2004. Production of nucleoside antibiotic from locally Isolated Streptomyces rimosus. M. Sc. Thesis. Coll. Sci., Univ. Basrah: 43pp).

Newman, D.J. \& Cragg, G.M. (2012)._Natural products as sources of new drugs over the 30 years from 1981 to 2010. J. Nat. Prod., 75: 311-335.

Pamplona-Roger, G.D. (1999). Encyclopedia of Medicinal Plants. Vol. 1 \& 2. $2^{\text {nd }}$ ed. Educ. Health Library, The European Union, UK: Pp. $128-150$.

Rahman, M.A.; Rahman M.A. \& Ahmed, N.U. (2013). Phytochemical and biological activities of ethanolic extract of Cassia hirsuta leaves. Bangladesh. J. Sci. Ind. Res., 48(1):43-50.

Rollas, S.; Gülerman, N. \& Erdeniz, H. (2002).Synthesis and antimicrobial activity of some new hydrazones of 4- fluorobenzoic acid hydrazide and 3-acetyl2,5-disubstituted-1,3,4-oxadiazolines.

Farmaco., 57: 171-174.

Royer, M.; Houde, R.; Viano, Y. \& Stevanovic, T. (2012). Non-wood forest products based on extractives-A new opportunity for the Canadian forest industry part 1: hardwood forest species. J. Food Res., 1(3):8-45. (Cited by St-Pierre, et al., 2018).

Sabri, F.Z.; Belarbi, M.; Sabri, S. \& Alsayadi, M.M.S. (2012). Phytochemical screening and identification of some compounds from Mallow. J. Nat. Prod. Plant. Res., 2(4): 512-516.

Saroya, A.S. (2011). Herbalism, Phytochemistry, and Ethnopharmacology. CRC Press, Taylor \& Francis Group, Science Publishers, USA: 427pp.

Shah, B. \& Seth, A. (2010). Textbook of Pharmacognosy and Phytochemistry. $1^{\text {st }}$ ed. Elsevier, Kundli, Haryana: 578pp.

Shariff, Z. U. (2001). Modern Herbal Therapy for Common Ailments. Nature Pharmacy Series. Vol. 1, Spectrum Books Limited, Ibadan, Nigeria in Association with Safari Books (Export) Limited, U K.: 99pp.

St-Pierre, A.; Blondeau, D.; Lajeunesse, A.; Bley, J.; Bourdeau, N. \& Desgagné-Penix, I. (2018). Phytochemical screening of quaking aspen (Populus tremuloides) extracts by UPLC-QTOF-MS and evaluation of their antimicrobial activity. Molecules., 23(1739): 1-21. doi:10.3390/molecules23071739.

Wolfender, J.L.; Eugster, P.J.; Bohni, N. \& Cuendet, M. (2011). Advanced methods for natural products discovery in the field of nutraceuticals. Chimia., 6: 400-406.

Yuksek, D.; Algul, O.; Dögen, A.; Tari, O.; Kucuk, E.; Otag, Z.F. \& Serin, M.S.(2013). Synthesis and antimicrobial activity evaluation of some benzimidazole and indole derivatives. Afr. J. Microbiol. Res., 7(17): 1708-1715. 